\title{
'Living on the edge'?
}

\section{A comparative study of processes of marginalisation among Polish migrants in rural Germany and Norway}

\author{
Jakub Stachowski and Kamila Fiałkowska
}

\section{International migrants in rural areas}

A growing geographical dispersion of intra-European migrants and their increasing presence in rural areas have become distinguishing features of migratory patterns in recent years (McAreavey 2017). Scholarly concern with this phenomenon is becoming extensive and has resulted in a rich body of empirical evidence illustrating the substantial national and regional diversity of receiving contexts (Górny and Kaczmarczyk 2018, McAreavey and Argent 2018, Rye and Scott 2018). The context and character of migration, its pace, and volume differently affect the degree of social change in the receiving areas and variously shape the pathways of accommodation and positions of migrants within social hierarchies of receiving rural communities (Jentsch and Simard 2009). Related to this is the observation made by Bock et al. (2016, 81 ), that rural 'integration and exclusion (...) is a matter of degree and dimension, and depends on the extent to which exclusion accumulates or eliminates in the intersection of legal, market and civil integration at different levels.'

The goal of this chapter is to study the processes by which migrants are marginalised in rural areas through a comparative analysis of two cases of labour migration from Poland to rural Germany and Norway, demonstrating two types of occupational concentration: in agriculture and in fish production respectively. We draw on ethnographic data gathered independently by the authors in two different research settings. While acknowledging the multifaceted character of marginalisation processes (Vasas 2005, Bernt and Colini 2013), we limit our analysis to the intersecting dimensions of migration regimes, sectoral concentration of the migrants within local industries, and the materiality and settlement structure of the hosting areas. We pay attention to temporal dimensions, and analyse marginalisation not as an achieved state, but as developing within specific structural conditions. The comparison of the two cases enables us to view patterns of international migration to rural areas not as isolated phenomena, but as entangled within wider global and international interconnections (Woods 2007) which mould into specific glocalised forms (Robertson 1994). 
The first case is the once widely popular seasonal migration from Poland to German agriculture, the other, a more recent non-seasonal migration from Poland to Norwegian salmon production. The German case is an example of a seasonal, temporary labour migration from Poland that stretches back to the mid-nineteenth century and remains popular (Kępińska and Stark 2013, Wagner et al. 2013). The Norwegian case is of relatively recent origin and has been prompted by Poland's accession to the EU in 2004. It has also been highly intensive in terms of numbers and cross-border mobility, and within its short duration developed traits of permanence (Friberg 2012).

Our intention is to demonstrate what forces are at play in two quite distinct receiving contexts and how migrants accommodate themselves to them. We illustrate that the marginalisation of migrants manifests itself differently in these contexts due to their position in rural labour markets and within material rural space. At the same time, migrants are not simply victims of oppressive structural forces, but also display an array of agentic competences, making sense of their situation, achieving a degree of control over their lives and being able to pursue their life plans (O'Reilly 2012a). As such, they are able to compensate for and to somewhat mitigate the effects of marginalisation.

\section{At the margins of what? Marginalisation, migration, and rural areas}

In a broad sense, the notion of marginalisation invokes connotations of periphery and denotes a restricted or underprivileged position of an individual or a group within a given social hierarchy (Vasas 2005). It is closely related to the notion of exclusion and integration and designates limitations in political, social, and cultural rights as well as various forms of social disadvantage such as poverty, discrimination, or inequality (Bernt and Colini 2013, Mowat 2015). Marginalisation is not a static condition but a process that involves complex mechanisms depriving people of access to resources or participation in various domains of social life (Vasas 2005). While keeping in mind this multifaceted character of the processes of marginalisation, in this chapter we focus on selected aspects. One central dimension is the migrants' location in the labour market, work arrangements, and how these shape the outcomes and strategies inscribed in the process of migration and/or settlement in rural areas. Conventionally, labour migrants have been depicted as occupying an underprivileged position in hosting societies (Piore 1979, Standing 2011). Concentration of migrants within particular occupational sectors often leads to the development of 'immigrant niches' adding to their marginal position in receiving contexts (Waldinger and Lichter 2003). Research has shown how such occupational concentration of migrants within low-skill sectors is augmented by the employers' explicit targeting and selection among groups that lack power, a perception of migrants as particularly suited for certain 
jobs or exhibiting an exceptional work ethic (MacKenzie and Forde 2009, Holmes 2013).

The interplay between marginalisation and place is important for this analysis. While literature on the intentions of settlement in the immigration country informs us that contact with the natives is crucial in forming a place attachment and making settlement decisions (Søholt et al. 2012, Brunarska and Toruńczyk-Ruiz 2019), the scholarship on international rural migration illustrates how problematic it may be. Lever and Milbourne (2017) have demonstrated how the intersection of labour market and spatial positioning renders migrants invisible in the local community. Similarly, Wagner et al. (2013), based on the case of labour migration from Poland to German agricultural production, showed how such conditions result in an ambiguous self-perception among migrants. On the one hand, they view themselves as occupying a marginal position in the social structures of the receiving communities, on the other, they are conscious of their pivotal role in the industry. Andrzejewska and Rye (2012), who researched seasonal workers in Norway, found that the geographical isolation of the farms and the long work hours suppress the possibility to engage in the local community and develop social relationships with the local Norwegian population.

\section{Polish migration to Germany and Norway - two contexts, two stories}

Polish intra-European migration eludes a single conceptualisation and has been shaped throughout the years by changing policies regulating the crossborder movements, access to jobs and settlement of Polish migrants abroad. In the aftermath of the collapse of communism, migration from Poland was an important livelihood strategy and has been labelled 'incomplete' (Jaźwińska and Okólski 2001) due to its largely temporary and circular character. Poland's accession to the European Union in 2004 granted a larger degree of freedom of movement for Polish citizens. Similar to their earlier migration movements, the post-2004 migratory processes were also largely analysed as temporal, and their transnational and 'liquid' (Engbersen and Snel 2013), or 'intentionally unpredictable' (Eade et al. 2007), character was emphasised. At the same time, treating intra-European Polish migration as in a state of constant flux would be an oversimplification, as evidence from major receiving countries clearly reveals patterns of permanence. In the case of Germany, the circular migration for many became a lifelong project to the extent that one can talk about 'permanent temporariness' ( $c f$. Martin 2001). In the case of Norway, settlement is clearly observed, for instance in the transnational rearrangements of family lives (Friberg 2012).

The 1989 collapse of the iron curtain opened new avenues for migration from Poland to Germany ( $c f$. Cyrus and Vogel 2006). A high number of irregular Polish migrants in Germany and the labour demand of the 
German farmers resulted in a bilateral agreement legalising the access of Poles to seasonal employment in Germany, signed as early as December 1990 (Okólski 2004). It became one of the few possibilities for legal employment in the west for the growing numbers of Polish citizens. The number of seasonal workers grew steadily, reaching nearly 300,000 workers on the eve of Poland's EU accession in 2004 (Kępińska 2013, 539). While the inclusion of Poland in the EU granted a greater degree of freedom of movement to its citizens, Germany decided to introduce and maintain the transitional period for a maximum length of seven years (as regulated in the Accession Treaty). In practice, this restricted the freedom of movement of workers from the acceding countries until 2011, apart from those working on the basis of the seasonal work agreement. While the country hosts a substantial Polish diaspora numbering between 1.5 million to 2 million people (Nowosielski 2016), many of whom are settled but living transnational lives (Barglowski 2019), it is also evident that thousands of workers continue to circulate between the countries (Wagner et al. 2013).

While not a regular member of the EU, through its membership in the European Economic Association (EEA), Norway participates in the policy of a cross-border flow of people, capital, services, and goods. This fact has had far-reaching implications for the patterns of migration in the country. While Polish migrants were no strangers to Norwegian society before 2004 (Godzimirski 2005), as a result of the opening of the Norwegian labour market, they have soon become the biggest group of migrants in the country, totalling today approximately 100,000 registered persons (Statistics Norway 2019). Similarly to Germany, Norway upheld the transitional period, but only for a period of five years. Between 2004 and 2009, the conditions for obtaining a residence permit demanded a full-time work offer from the employer and a guarantee of wages following Norwegian standards. However, a bulk of migration has been organised as posted workers and through recruitment agencies, which has been an effective way of avoiding collective agreements such as equal wages (Friberg 2013). In May 2009, the transitional period ended and, from this time on, holding a part-time contract was sufficient for obtaining permission to stay and work (Friberg et al. 2013). The reports of 'social dumping' from labour intensive sectors in which many Polish migrants concentrate, for instance construction, agriculture, or manufacturing, have led to state intervention and the implementation of measures such as a generalisation of wages and greater control in several sectors (Friberg 2013). From 2018 , the generalisation of wages also includes the fish industry.

\section{Researching migrants in rural areas - methods and challenges}

The data used in this chapter come from two independently conducted projects. In both cases, the researchers were guided by the logic of an 
ethnographic approach, combining in-depth interviews and participant observation. The common objective was to gain an understanding of Polish migration as a process developing in time and space, and the consequences it generates for the migrants.

The German case comes from multi-sited fieldwork in Poland and Germany lasting for eight months and stretching between 2010 and 2012. Fieldwork was conducted in the local community in Poland, where seasonal migration was a widely popular livelihood strategy, and in Germany, at the place of work for the seasonal migrants (see Wagner et al. 2013). Data collection comprised covert and overt participant observation, including five weeks of employment as a strawberry picker in Germany. The author was thus able to live and work with the migrants, and observe the daily work-life rhythm at the farm, which employed over 200 people in the high season. Importantly, due to mistreatment and malpractices in the work and living spaces of the migrants, some of the findings were only able to be obtained if the identity of the researcher was concealed. Such a method of data collection inevitably raises ethical concerns due to the workers' lack of awareness of the aim of her seasonal employment. Thus, the questions of protecting the identity and privacy of the participants were of crucial importance and had to be handled with a great level of reflexivity and care for the co-workers, all of which were addressed by the author in her work and the institution in which she was based. Towards the end of the fieldwork, Fiałkowska disclosed the aim of her seasonal employment to trusted co-workers, with whom she discussed the observations, and she acquired their consent to use the data in her work. These touched upon topics that were important parts of the migrants' experiences and workers' discussions (for instance, arrangements related to living in Poland and working in Germany, accommodation and working conditions, and the general wellbeing of the migrant workers). This was combined with 40 semi-structured in-depth interviews conducted in Poland with the seasonal workers. Altogether, this allowed for a discussion regarding the observations and to inter-subjectively reinforce the accuracy of the interpretations. To protect the co-workers and interviewees, their names and the place of the fieldwork have been anonymised.

In the case of Norway, the fieldwork has been conducted among Polish migrants who live and work in one of the rural municipalities located by the Norwegian coast. From 2004 onwards, the area has attracted a substantial number of east and central European labour migrants who found employment at the local fish-processing plant. Today, the share of the migrant population in the municipality is over 25 per cent and the Polish local population numbers approximately 200 persons. The fieldwork was divided into a series of ethnographic stays conducted between May 2016 and May 2018. It combined formal and informal interviews, participant observation, visits to the fish-processing plant where the majority of the migrants worked, and visits to migrants' houses. During the fieldwork, 30 in-depth interviews with 
36 Polish migrants were conducted. They included 19 men and 17 women ranging from their early 20 s to early 60 s. Twenty-three of the participants were in their late $20 \mathrm{~s}$ or $30 \mathrm{~s}$. An average time the interviewees had lived in the locality was six and a half years. The approach to the interviews was biographical (Roberts 2002). Its aim was to understand how the situation of the migrants in the locality changes with time. The themes discussed were their living and working conditions, social relationships, rationale for arriving and staying, their everyday concerns, and experiences and practices. All the interviews were conducted in the informants' first language, most of them in the setting of the migrants' private living spaces. The conducted fieldwork was entirely overt.

Due to obstacles encountered, the recruitment of the informants combined purposive and opportunistic sampling (O'Reilly 2012b). Two gatekeepers have been central for establishing contact with the participants and aiding the recruitment process. An important issue that emerged during the fieldwork was the social visibility of the local Polish community. This prompted the researcher to reflect upon issues of ethics, and to anonymise the identity of the participants and the name of the locality.

\section{Living on the edge(s) of rural societies}

In this chapter, we analyse and compare two domains of migrants' lives across the two contexts: work arrangements and spatial aspects of their lives in the community and beyond. We illustrate their impact on migrants' overall position in the receiving context and how migrants respond to them.

\section{At the edge of the local labour market}

Unskilled labour in German agriculture and Norwegian fish production have been largely abandoned by local workers and gradually replaced by international migrant workers. As a result, the continuous flow of migration over the years has led to an occupational concentration of workers with a foreign background.

The migration trajectory from Poland to Germany built around circularity and concentration in agriculture has been a result of the above mentioned bilateral agreement in 1990, which continued after 2004 and up to 2011, independently of restrictions following from Germany's transitional arrangements. Access to this form of employment was organised through informal networks, on which workers were dependent. At the time of the fieldwork (2010-2012), many of Fiałkowska's respondents were expected to pay an informal fee of 20 up to as much as 100 euros to a senior employee, who often also acted as a middleman for such an arrangement.

Faced with limited options for other kinds of employment, migrants had to be resilient and obedient at work in order to secure employment for the next 
season. Often unclear employment conditions caused an intensification of work (Smith 2006) and competition among the workers, breaking down loyalties and cooperation. This was critically addressed by one of the interviewees, Iza. She worked alongside her cousin and friend, forming a team, for which the cousin was made responsible. The work was arranged by her cousin, who had to earn the trust of the employer to be allowed to 'bring' someone else to work. In the interview, Iza explained how this happened:

\section{[...] they slept for five hours, there was a lot of work [...]. The German stood and watched them in the field. Something's not right and he kicked the box with strawberries and made you start over from the beginning of the row. So, from what she said, it was just terrible. But as it turned out later, it was about choosing the best workers, who later could recruit others.}

Insecurity related to future employment translates into an intensification of work and self-exploitation, which also emerges from Iza's account: 'she said that once I decided to come to work, I have to endure as long as the boss wants, and not to quit after a week.' As she explained, this would negatively affect her cousin's situation, who depended on this form of employment. This adds to the burden of the employees, who realise that their position and relationship with the employer is determined not only by the quality of their work but also by those whom they recruited. Yet they learned to rationalise and to adapt to such situations. While work in agriculture and the circulation between the two countries was not simply a matter of choosing but often a necessity due to financial difficulties in the home country, the seasonal migration was often referred to as inscribed into their lives, or as a desire to go 'when the spring comes and you will smell the soil' (cf. Wagner et al. 2013, 46).

Yet migrants were acutely aware that they do the jobs locals will not do. 'They laughed at us, Polnishe Maschine they say' is what another respondent overheard from a few locals employed on higher positions on the farm. Such attitudes unveil their dehumanising approach towards the employees, which legitimises foreign workers' exploitation, all of which they are aware of.

Negotiating their marginal social and labour market position, the interviewees referred to what Morawska (2001) called a 'cultural kit,' a combination of features such as reliability or diligence inextricably linked with national identity. This is evident in the narrative of Grzegorz, who has been a permanent seasonal migrant for the last 20 years. In a conversation that took place just before his forthcoming apple-picking season, he stressed the reliability of Polish workers and their high work ethic.

The boss tries to be fair because he knows that who else would come here to work, right? He will not turn to Germans, because they won't come. They won't come to work in the field, and not for this money [...] 
Constructing the figure of an 'ideal worker' (MacKenzie and Forde 2009) and contrasting it with the locals' approach to work, Grzegorz's statement also points to how migrants rationalise, normalise, and narrate the story of their migration. Paradoxically though, by becoming an 'ideal worker' and enhancing their employability by appealing to their 'cultural kit,' migrant workers contribute to their marginalisation by becoming exactly the kind of workers the employers need - hardworking, flexible, and with few demands. Their marginal labour market positioning as well as social invisibility resembles in some aspects the situation of Polish migrants in Norway.

In the Norwegian case, migrants cluster predominantly within the local salmon industry. After 2004, the industry started to rely increasingly on the recruitment of migrant workers and experienced a rapid growth in its share of foreign labour force. As a result, the company that employs most of the migrant workers in the study locality has gradually become ethnically segmented. With only a few exceptions, the physical tasks of fish processing, such as slaughtering, cutting, filleting, and packing, were performed by workers with a foreign background. Increasing migration to the locality prompted competition between the migrant workers, creating a pressure to improve performance and resulting in an overall intensification of work. In addition, the workers over time experienced a worsening of their working conditions. From the full-time permanent contracts offered to them during the first years after the EU-extension, the employment policy changed to an offer of 80 per cent permanent contract, preluded by a lengthy trial period. This change contributed to the internal segmentation of the foreign workforce, with more recent arrivals experiencing an increased insecurity in their work situation. Dariusz shared his thoughts on this issue:

They don't give us the rights we deserve. If I was Norwegian, I think they would give me a 100 per cent contract (...) This system makes you insecure. It gives people the feeling that if they don't work hard, they are not good enough. They squeeze them like lemons for two years, and then people can't work properly after they get the permanent contract. They are too exhausted after the two-year struggle for the contract.

(Dariusz, early 30s)

The narratives of the migrants concerning the working conditions were often framed as exploitation and instrumental treatment. They reflected the awareness of being treated as a flexible and disposable labour force, and not as long-term assets.

The occupational concentration of the Polish migrants has wider implications for their marginalisation. The organisation of work in the fish industry severely limited possibilities for the acquisition of the Norwegian language, as migrants socialised almost exclusively with other migrants. Some have spent years performing menial, physically demanding tasks in the fish industry, prioritising 
financial gains but at the same time risking a deterioration of their health and wellbeing, and limiting the opportunities for inclusion in other spheres of the local community. While some have managed to find other jobs in the local labour market, for most, changing jobs was a risky venture that may put strain on an otherwise fragile life. As one of the female informants, Krystyna confessed:

INTERVIEWER: What are the pros and cons of your job?

KRYSTYNA: Salary is a positive side. The negative side is that my health deteriorates. Your joints, back, and psyche are worn-out. But when it comes to the salary, it is ok.

INTERVIEWER: Do you consider changing this job?

KRYSTYNA: Yes, I do.

INTERVIEWER: What are the real chances for making it come through?

KRYSTYNA: I think that chances are good but there is... I don't have courage. You think, what is going to happen, right? (...) there is this waiting time in the job office. Two months [waiting time before one is entitled to benefits in case of voluntarily quitting job]. And what then? What about finances, then? So, I refrain from doing that for the time being.

(Krystyna, mid 40s)

The above story illustrates sentiments that are characteristic for many migrants. The prolonged stay in the locality is a form of sacrifice. It involves an improvement of their financial situation and gradual settlement, but at the same time offers very few perspectives on mobility in the local labour market, and may in turn result in consolidating migrants' position within the second sector of the labour market (Piore 1979).

\section{Spatial edges}

In this section, we discuss how migrants' marginalisation is related to their spatial distribution within the respective localities, and how this reflects their overall position within the hosting communities.

Becker $(2010,7)$ has metaphorically conceived seasonal migrant workers in Germany as an 'army of goblins': fairylike creatures, whose role is reduced to performing a certain job and then vanishing. The workers arrive, do the job and return home largely unnoticed by the mainstream society. Their invisibility, also experienced by the researcher during the fieldwork, is strengthened by a clear spatial separation, as migrants are accommodated in remote areas where work is performed. Accommodation must be provided by the employer in case of seasonal work in agriculture (for which migrants are usually charged). Often it is a cellar or the attic in an outbuilding - in the analysed case, approximately 200 co-workers were accommodated in containers and caravans, forming a sort of ethnic colony on the side of a little-used road at the margins of the village, in the vicinity of the farmlands. 
The minimum conditions set in the law for accommodation are: a minimum of six square meters per person, a maximum of six persons in a room - women and men separately, bed and a cupboard should be provided for every person, as well as a chair and place by the table, and there should be a place to prepare food - minimum one kitchen stove per two persons, access to the fridge, one toilet per eight persons, and one shower per 10, access to a washing machine and access to a first aid kit. These were suggestions for newly built accommodations. A departure from these norms has been tolerated over time and in practice.

In the analysed case, the containers were too small to host six people, not to mention their belongings, which were stored under the beds since there was no cupboard (see Figure 7.1 for an example). The number of showers or toilets was below the required amount, there was a lack of hot water and limited access to the washing machine. Facing frequent power cuts, workers used candles, but no fire extinguishers were provided. Interviews with other seasonal workers confirm that these observations from the field are still frequently experienced problems, while there is a limited awareness of the workers' rights regarding the minimum standards of accommodation (Wagner et al. 2013).

Intersecting with the structural dimensions, most notably with the mentioned earlier sectoral concentration and type of work, migrants are practically excluded from the life of the host community. They spend most

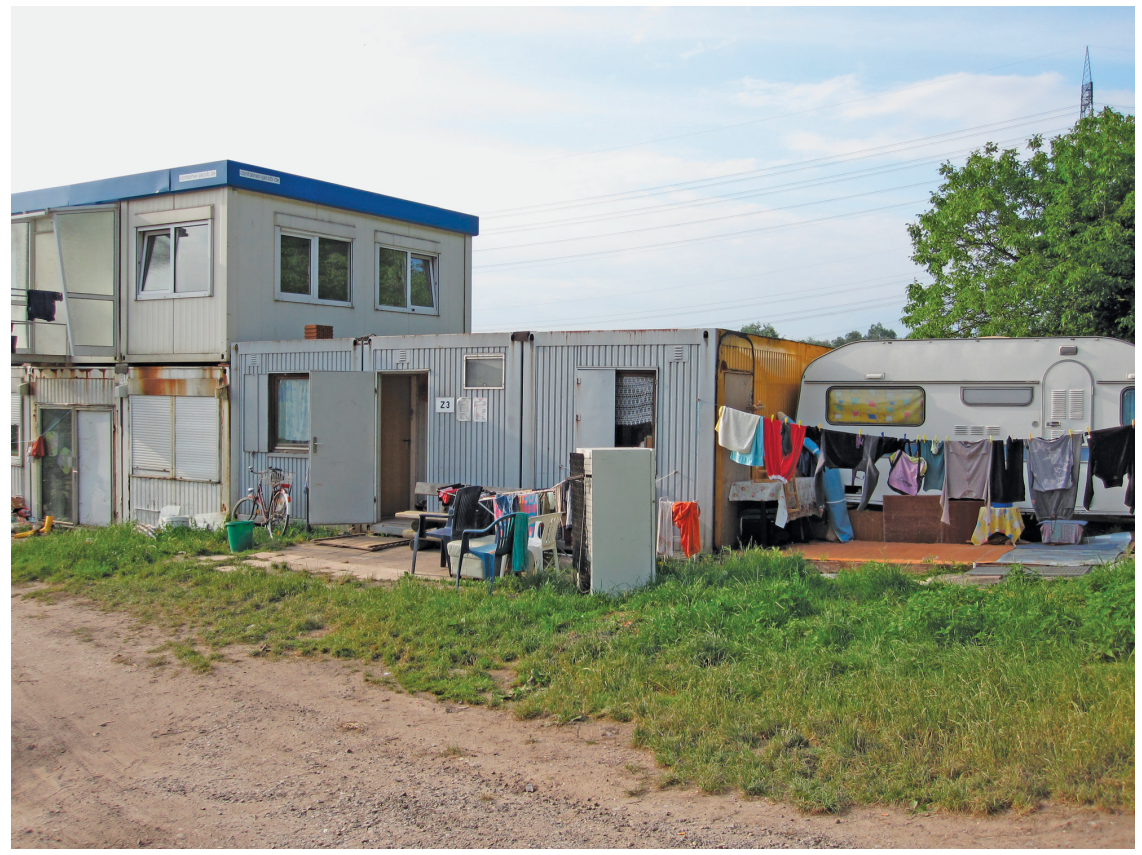

Figure 7.I Accommodation of seasonal migrant workers in Germany, 2010 (Photo credit: Kamila Fialkowska) 
of their time working and then resting, which limits their opportunities to have outside contacts or relationships, or to seek help or advice when needed. Moreover, working and living alongside their compatriots, they hardly ever have a chance to learn or practice the local language. The host community usually means the farm, so the most important issue here is what kind of relation they have with their co-workers, employer, or their employer's representatives. 'We came here to work, not to take a rest' was an oft-repeated phrase, which helped to build resilience in the face of poor accommodation, a demanding job, and the demeaning treatment of workers. The temporality of this arrangement made it easier to consent to it. Regular seasonal workers on the farm would return to the same container every other year. As such, they could live with their former colleagues, which increased their sense of comfort as well as the ability to adjust the containers to their needs, domesticating the unhomely space (Boccagni 2014).

In the Norwegian case, the local spatial distribution of Polish migrants and their living arrangements were different. Unlike the German case, the occupational concentration did not transcend into specific housing patterns. One of the reasons was the fact that Norwegian employers are not obliged to provide accommodation for the migrant workers. Migrants are thus responsible for finding and arranging their own living places in the local housing market. During the fieldwork, no specific area in the local housing and settlement structure where migrants would concentrate was identified. The non-seasonal character of the work in the fish industry has facilitated a longer-term stay of many migrants and invited them to invest in better housing arrangements. Despite the sparsely distributed population and frequently experienced isolation caused by considerable distances between villages in the locality, and the fact that 90 per cent of the housing structure consists of detached houses, migrants belonged to the 'natural' existing settlement structure (see Figure 7.2 for an example). Nevertheless, the material and geographical conditions of the locality were experienced by many as burdensome, as they imposed geographical barriers which needed to be traversed on a daily basis. Radek, in his late 20 s, was among those who reflected upon this:

There is not so much motivation to be (participate) everywhere, let's say play basketball, because everything is far away. Everything is so spread out here (...) During the weekends... in Poland when we used to go out with our peers to a restaurant or a pub, it was easy to get back because there was public transportation. Here you have to drive.

(Radek, late 20s)

The material structure of the location necessitated migrants to relate to it and to domesticate it. As Radek's experiences indicate, long distances could effectively limit migrants' participation in spare-time activities and socialisation with other inhabitants in the locality (Cass et al. 2005). As such, the 
experiences of the locality were often described as an ambivalent mixture of rural idyll and the drudgery of everyday material obstacles (Woods 2011). At the same time, such experiences have not refrained many from reuniting with their families in Norway and purchasing properties. Both are tangible signs of an intention to stay longer term. Ela, who together with her child joined her husband in Norway, reflected upon this:

I don't want to move anywhere else (outside this particular location in the area) (...) We're looking for a house here, but we can't find one (...) It has to be here. We're close to the doctor's office and to school ... and the shop is close... (...). We want to buy a house because we want to have something that is ours. I want to feel that this is my place, I want to feel that I am coming back home, not to a soulless apartment.

(Ela, early 40s)

The quotation illustrates place-attachment and the development of a feeling of being at home. For house owners or those considering buying property, this was often an important life stage associated with stability and a 'grounding' of life (Bygnes and Erdal 2016).

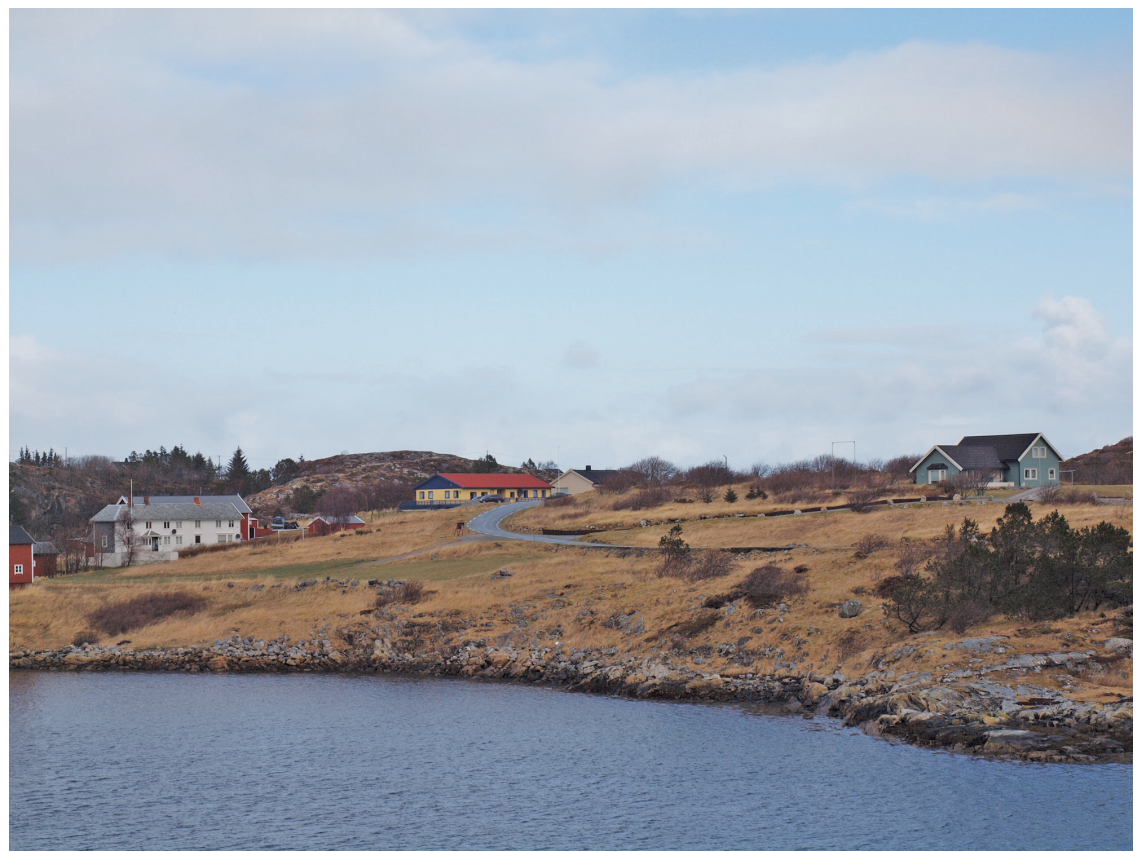

Figure 7.2 An example of migrants' housing in the Norwegian case (Photo credit: Jakub Stachowski) 


\section{Thriving on the edges of rural communities - final thoughts}

In this chapter, we have compared two cases of international migration from Poland to different rural contexts in Germany and Norway respectively. We placed our analysis within a wider context of migration regimes but paid particular attention to industrial and material aspects of receiving local contexts. As the initially quoted observation by Bock et al. (2016) suggests, exclusion and integration, but also marginalisation, work intersectionally and are the results of interaction and overlap between various factors.

The role of working conditions, migrants' position in the local labour market, and the fact that they are largely contracted to perform certain types of physical, unskilled tasks were central factors in this analysis. These conditions have proved central in grasping the workings of the marginalisation processes, as they illustrate how the disadvantaged position of the migrants is impacted by their work arrangements. While, in both cases, a combination of recruitment strategies and the volume of migration has led to the formation of ethnic niches (Waldinger and Lichter 2003), their existence intersects differently with another dimension emphasised in the analysis, namely the rural place. In the case of the German agriculture, the combination of spatial and physical emplacement of work in the fields and seclusion through camp accommodation pushes migrants drastically to the edge of, and out-of-sight in, the local community. In Norway, however, despite the high occupational concentration of the migrants, the workings of spatial marginalisation differ. Despite the frequently experienced social isolation as a result of the material attributes of the place, migrants are spatially distributed within the 'naturally' existing settlement structure of the location.

While the German case features seasonal production and, as such, presupposes largely circular migration, throughout its duration over many years, the migration has evolved into a recurring circuit. One of the reasons the seasonal migration of Poles to Germany developed as a life-long project for some of the migrants has been long-lasting limitations inscribed in the migration regime that supported circulation rather than settlement. By contrast, through its membership in the EEA, Norway grants EU-migrants a higher degree of freedom to seek employment and settle down. In addition, the non-seasonal character of the work in fish production invites and facilitates some of the Polish migrants to establish long-term roots in the locality. These factors affected the ways in which the respective streams of migration developed.

As the German case showed, the circular seasonal migration turned into a permanent phenomenon in the researched case, with profound implications for migrants' personal life trajectories, as well as their families and local communities ( $c f$. Fiałkowska 2019). In this case, the continuous treatment of the home country by migrants as a primary point of reference may facilitate 
rationalisations of their marginal positions. Furthermore, a belief in the good reputation of the Polish migrant workers who are vital in the success of the harvesting season in Germany may be also a compensatory strategy. In Norway, on the other hand, there is a tendency towards a more permanent settlement, visible through the acquisition of properties in the locality, family reunifications, and place attachment. Creating a home and focusing on constructing familiarity in the relative social isolation and relatively low labour-market position is how they exercise their agency.

As such, these examples are manifestations of migrants' agentic capabilities. Narratives of the migrants and concrete practices reveal various ways of making sense of their situation, rationalising and, in consequence, mitigating the experience of marginalisation experienced otherwise. Considerations of migrants' agency, viewing them as reflexive and able to exercise some control over their actions, and as negotiating the asymmetrical social relations they experience, enables us to better comprehend and problematise the processes of marginalisation in receiving rural areas.

One of the final reflections emerging from the analysis is the importance of keeping scholarly pace with the dynamically changing character of rural international migration. Migrant positionalities in rural contexts are not constant but rather continuously evolving as a result of cross-cutting mechanisms of exclusion/inclusion within respective migration regimes and the ways of negotiating these conditions by the migrants.

\section{Acknowledgements}

The chapter is result of the 2017-2022 Global Labour in Rural Societies research project financed by the Norwegian Research Council (grant no. 261854/F10). The authors wish to thank the external reviewers for their comments on the manuscript. Funding from the Norwegian University of Science and Technology has made possible open access publishing of the chapter.

\section{References}

Andrzejewska, J. and J.F. Rye. 2012. 'Lost in Transantional Space? Migrant Farm Workers in Rural Districts.' Mobilities 7(2): 247-268. DOI:10.1080/ 17450101.2012.654996.

Barglowski, K. 2019. Cultures of Transnationality in European Migration: Subjectivity, Family and Inequality. Abingdon: Routledge.

Becker, J. 2010. Erdbeerpflücker, Spargelstecher, Erntehelfer: Polnische Saisonarbeiter in Deutschland, temporäre Arbeitsmigration im neuen Europa. Bielefeld: Transcript Verlag.

Bernt, M. and L. Colini. 2013. 'Exclusion, Marginalization and Peripheralization. Conceptual Concerns in the Study of Urban Inequalities.' Working Paper. Leibniz Institute for Regional Development and Structural Planning. 
Boccagni, P. 2014. 'What's in a (Migrant) House? Changing Domestic Spaces, the Negotiation of Belonging and Home-making in Ecuadorian Migration.' Housing, Theory and Society 31(3): 277-293. DOI:10.1080/14036096.2013.867280.

Bock, B.B., G. Osti and F. Ventura. 2016. 'Rural Migration and New Patterns of Exclusion and Integration in Europe.' In Routledge International Handbook of Rural Studies, edited by M. Shucksmith and D. Brown, 71-84. Oxon, New York: Routledge.

Brunarska, Z. and S. Toruńczyk-Ruiz. 2019. 'Through Attachment to Settlement: Social and Psychological Determinants of Migrants' Intentions to Stay.” Journal of Ethnic and Migration Studies: 1-19. DOI:10.1080/1369183X.2018.1554429.

Bygnes, S. and M.B. Erdal. 2016. 'Liquid Migration, Grounded Lives: Considerations about Future Mobility and Settlement among Polish and Spanish Migrants in Norway.' Journal of Ethnic and Migration Studies 43(1): 102-118. DOI:10.1080/ 1369183X.2016.1211004.

Cass, N.E. Shove and J. Urry. 2005. 'Social Exclusion, Mobility and Access.' The Sociological Review 53: 539-555. DOI:10.1111/j.1467-954X.2005.00565.x.

Cyrus, N. and D. Vogel. 2006. 'Managing Access to the German Labour Market: How Polish (Im)migrants Relate to German Opportunities and Restrictions.' In Illegal Immigration in Europe: Beyond Control?, edited by F. Düvell, 75-105. London: Palgrave Macmillan UK.

Eade, J., S. Drinkwater and M. Garapich. 2007. Class and Ethnicity: Polish Migrant Workers in London: Full Research Report. ESRC End of Award Report. RES-00022-1294. Swindon: ESRC.

Engbersen, G. and E. Snel. 2013. 'Liquid Migration: Dynamic and Fluid Patterns of Post-accession Migration Flows.' In Mobility in Transition: Migration Patterns after EU Enlargement, edited by B. Glorius, I. Grabowska-Lusińska and A. Kuvik, 21-40. Amsterdam: Amsterdam University Press.

Fiałkowska, K. 2019. 'Remote Fatherhood and Visiting Husbands: Seasonal Migration and Men's Position within Families.' Comparative Migration Studies 7(1): 2. DOI:10.1186/s40878-018-0106-2.

Friberg, J.H. 2012. 'The Stages of Migration. From Going Abroad to Settling Down: Post-accession Polish Migrant Workers in Norway.' Journal of Ethnic and Migration Studies 38(10): 1589-1605. DOI:10.1080/1369183X.2012.711055.

Friberg, J.H. 2013. The Polish Worker in Norway. Emerging Patterns of Migration, Employment and Incorporation after EU's Eastern Enlargement. Ph.D. Diss., University of Oslo.

Friberg, J.H., J.E. Dølvik and L. Eldring. 2013. Arbeidsmigrasjon til Norge fra Øst- og Sentral-Europa. Temanotat. Oslo. Fafo.

Godzimirski, J.M. 2005. Tackling Welfare Gaps: The East European Transition and New Patterns of Migration to Norway. NUPI.

Górny, A. and P. Kaczmarczyk. 2018. 'A Known but Uncertain Path: The Role of Foreign Labour in Polish Agriculture.' Journal of Rural Studies 64: 177-188. DOI:10.1016/j.jrurstud.2017.12.015.

Holmes, S.M. 2013. Fresh Fruits, Broken Bodies. Migrant Farmworkers in the United States. Berkeley: California Series in Public Anthropology.

Jaźwińska, E. and M. Okólski. 2001. Ludzie na huśtawce: Migracje między peryferiami Polski i Zachodu. Warszawa: Wydawnictwo Naukowe Scholar. 
Jentsch B. and M. Simard. 2009. 'Conclusion: Comparative Perspectives on Rural Immigrants' Integration.' In International Migration and Rural Areas, edited by B. Jentsch and M. Simard, 179-196. Farnham and Burlington: Ashgate.

Kępińska, E. 2013. 'Gender Differentiation in Seasonal Migration: The Case of Poland.' Journal of Ethnic and Migration Studies 39(4): 535-555. DOI:10.1080/ 1369183X.2013.745231.

Kępińska, E. and O. Stark. 2013. 'The Evolution and Sustainability of Seasonal Migration from Poland to Germany: From the Dusk of the 19th Century to the Dawn of the 21st century.' International Review of Economics and Finance 28: 3-18. DOI:10.1016/j.iref.2013.05.003.

Lever, J. and P. Milbourne. 2017. 'The Structural Invisibility of Outsiders: The Role of Migrant Labour in the Meat-processing Industry.' Sociology 51(2): 306-322. DOI:10.1177/0038038515616354.

MacKenzie, R. and C. Forde. 2009. 'The Rhetoric of the "Good Worker" versus the Realities of Employers' Use and the Experiences of Migrant Workers.' Work, Employment and Society 23(1): 142-159. DOI:10.1177/0950017008099783.

Martin, P. 2001. There is Nothing More Permanent than Temporary Foreign Workers. Backgrounder. Center for Immigration Studies. https://cis.org/Report/ There-Nothing-More-Permanent-Temporary-Foreign-Workers.

McAreavey, R. 2017. New Immigration Destinations: Migrating to Rural and Peripheral Areas. New York: Routledge.

McAreavey, R. and N. Argent. 2018. 'New Immigrant Destinations (NID) Unravelling the Challenges and Opportunities for Migrants and for Host Communities.' Journal of Rural Studies 64: 148-152. DOI:10.1016/j.jrurstud.2018.09.006.

Morawska, E. 2001. 'Structuring Migration: The Case of Polish Incomeseeking Travelers to the West.' Theory and Society 30(1): 47-80. DOI:10.1023/ A:1011081228016.

Mowat, J.G. 2015. 'Towards a New Conceptualization of Marginalization.' European Educational Research Journal 14(5): 454 476. DOI:10.1177/1474904115589864.

Nowosielski, M. 2016. Polskie organizacje $w$ Niemczech. Stan i uwarunkowania. Poznań: Instytut Zachodni im. Zygmunta Wojciechowskiego, Poznań.

Okólski, M. 2004. Seasonal Labour Migration in the Light of the German-Polish Bilateral Agreement. OECD. DOI:10.1787/9789264108684-en.

O'Reilly, K. 2012a. International Migration and Social Theory. London: Palgrave Macmillan.

O'Reilly, K. 2012b. Ethnographic Methods. London: Routledge.

Piore, M.J. 1979. Birds of Passage: Migrant Labor and Industrial Societies. Cambridge University Press.

Roberts, B. 2002. Biographical Research. Maidenhead Berkshire: Open University Press.

Robertson, R. 1994. 'Globalisation or Glocalisation?' The Journal of International Communication 1(1): 33-52. DOI:10.1080/13216597.1994.9751780.

Rye J.F. and S. Scott. 2018. 'International Labour Migration and Food Production in Rural Europe: A Review of Evidence.' Sociologia Ruralis 58(4): 929- 952. DOI:10.1111/soru.12208.

Smith, C. 2006. 'The Double Indeterminacy of Labour Power: Labour Effort and Labour Mobility.' Work, Employment and Society 20(2): 389-402. DOI:10.1177/ 0950017006065109. 
Standing, G. 2011. The Precariat. The New Dangerous Class. London: Bloomsbury Academic.

Statistics Norway. 2019. Fakta om innvandring. www.ssb.no/innvandring-oginnvandrere/faktaside/innvandring.

Søholt, S., A. Aasland, K. Onsager and G.M. Vestby. 2012. 'Derfor blir vi her' innvandrere i Distrikts Norge. NIBR-rapport 2012: 5.

Vasas, E.B. 2005. 'Examining the Margins: A Concept Analysis of Marginalization.' Advances in Nursing Science, 28(3): 194-202. DOI:10.1097/ 00012272-200507000-00002.

Waldinger, R. and M.I. Lichter. 2003. How Other Half Works. Immigration and the Social Organization of Labour. Berkeley: University of California Press.

Wagner, M., K. Fiałkowska, M. Piechowska, M. and W. Łukowski. 2013. Deutsches Waschpulver und polnische Wirtschaft. Die Lebenswelt polnischer Saisonarbeiter. Ethnographische Beobachtungen. Bielefeld: Transcript Verlag.

Woods, M. 2007. 'Engaging the Global Countryside: Globalization, Hybridity and the Reconstitution of Rural Place.' Progress in Human Geography, 31: 485-508. DOI:10.1177/0309132507079503.

Woods M. 2011. Rural. New York: Routledge. 